\title{
Noninterest (Nonprofit) Income and Financial Performance at Turkish Commercial and Participation Banks
}

\author{
Aykut Karakaya $^{1} \&$ Bünyamin Er $^{1}$ \\ ${ }^{1}$ The Faculty of Economics and Business Administration, Karadeniz Technical University, Trabzon, Turkey \\ Correspondence: Bünyamin Er, Assistant Associate Professor, The Faculty of Economics and Business \\ Administration, Karadeniz Technical University, Trabzon, Turkey. Tel: 90-462-377-8778. E-mail: ber@ktu.edu.tr
}

Received: October 31, 2012

Accepted: November 22, 2012

Online Published: December 7, 2012

doi:10.5539/ibr.v6n1p106

URL: http://dx.doi.org/10.5539/ibr.v6n1p106

\begin{abstract}
The purpose of this paper is to examine the determinants of bank profitability and the relation between noninterest (nonprofit) income and bank performance for an emerging market, Turkey. The data set of the study is the 6 years data between 2005-2010 of the banks in question. In this study impact of capital adequacy, size of bank, credit rate, credit provision rate and general expenses on bank performance indicators are undertaken. At the end of analyses made it has been concluded that these variables in question have an impact on bank performance. The results show that capital adequacy, size and credits increase the bank performance whereas general expenses decrease it. Also it has been observed that performance of participation banks are higher than that of commercial banks. Finally, it has been observed that noninterest income increases equity capital adequacy.
\end{abstract}

Keywords: noninterest (nonprofit) income, participation banks, Turkey

JEL Classification: G21, G28

\section{Introduction}

The fact that interest is forbidden in Islam religion has caused Muslim's keeping away from this phenomenon. On the other hand the fact that there is lack of institutions alternative to conventional bank has caused that savings of these people shift to non banking fields like gold, currency and real estate. In consequence, it has been observed that these assets have been directed to fields which do not provide contribution to manufacturing and stayed idle in a sense. In order to prevent this negativity, financial institutions which operate based on noninterest work principle, which draw people's savings into economy and hence create additional sources for the development of the country have been established both in Turkey and in other Islam countries (Özsoy, 1997). The 2008 global financial crisis whose effect on financial markets still persists have turned the attentions worldwide to the Islamic banking system, activities of which is based on real sector. Although the system that operates based on participation to profit and loss and envisages risk sharing is known as noninterest banking or Islamic banking worldwide, it is described as participation banking in Turkey. In recent times the use of noninterest banking which has a small but growing share in global finance system has been becoming widespread as an alternative model in different countries with advanced finance systems as well as in Islam countries (Parlakkaya \& Çürük, 2011). Total asset size of $\$ 140$ billion of world noninterest banking sector in 1995 has reached $\$ 12.000$ billion at the end of 2010 .

Participation banks are Islamic financial institutions. The owners participate in the profits instead of earning interest. Participation banks put the funds they collect into use in such transactions as mudaraba, musharaka, murabaha, sherike and icare which find their places within Islamic law and are being used for centuries. Among these transactions is the mudaraba which is a privileged function that should be indispensible feature of participation banks. Because, with profit/loss sharing system, mudaraba system substitutes interest system in Islamic finance system. Notwithstanding this, majority of transactions of participation banks are murabaha transactions which means "buy cash- pay in installments" in commerce.

There are three types of banks in Turkish banking sector. These are commercial banks, development and investment banks and participation banks which are also known as noninterest banks. As of the third quarter of 2011, from asset size perspective participation banks constitute $4,4 \%$ of the banking sector which includes these 
three types of banks, from loan (fund) size perspective they constitute 5.8\%, and from branch network size they constitute $6.3 \%$. Despite their relatively small shares in total, due to the fact that these rates have been increasing steadily every year, it is likely that weight of participation banks in banking sector will increase in the coming years. The realizations illustrated in Graphic 1 in regards to participation banks have been enhancing this probability.

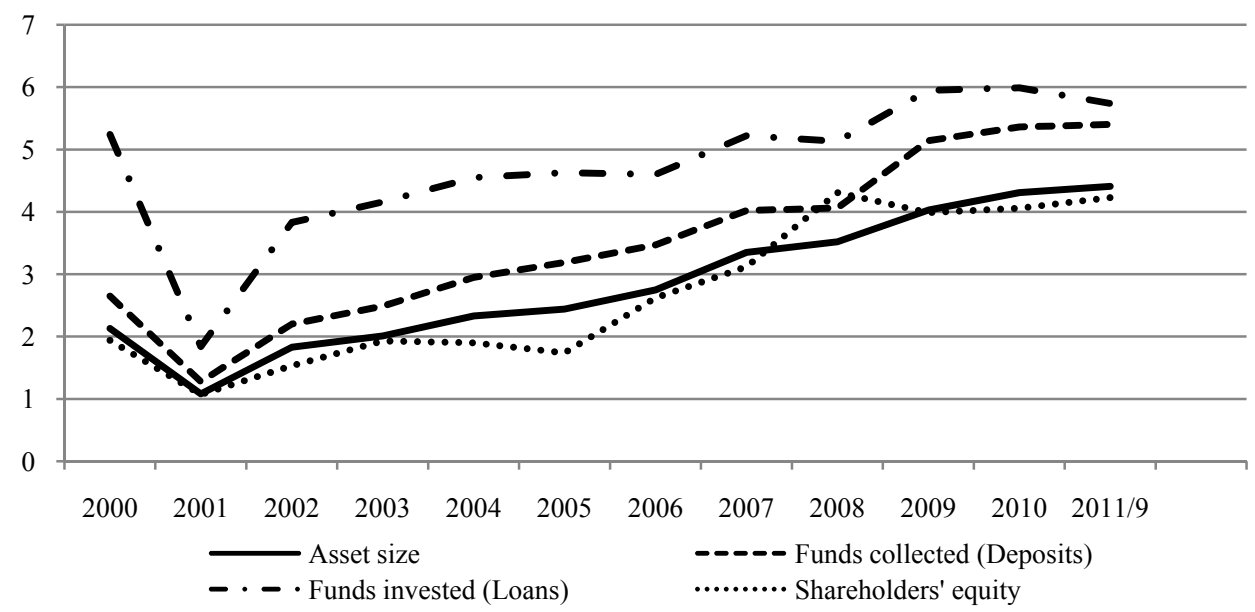

Figure 1. Market share of participation banks in turkish banking sector (\%)

Source: The Participation Banks Association of Turkey.

On the other hand, due to comprehensive deregulation process and information flow, rapid changes in the communications infrastructure and financial markets in the past 30 years, the banking sector has entered into an important change process. The deregulation process has increased the competition among the banks, non bank financial institutions and financial markets. In this competition environment banks have put into use new technologies which caused changes in their production and distribution strategies and led to big increase in their noninterest income. Correspondingly, because they perceive noninterest income less important many other banks have continued to adopt traditional banking strategies (De Young \& Rice, 2004).

The changes in information and communications technologies (internet, ATMs etc), in new intermediary technologies (e.g. asset securitization and credit rating) and expansions in financial instruments and markets (e.g. high-yield bonds and financial derivatives) have all taken place in the absence of deregulation. But the deregulation process allowed the banks to use these technologies more effectively and to adapt to new technologies. Majority of these technologies have led to increase in noninterest incomes for the banks.

From the perspective of commercial bank performances, outcomes of noninterest income are not very well known. When everything else is equal, an increase in noninterest income will increase the profit. Notwithstanding this, it is also necessary to underline that an increase in noninterest income can also take place due to banks' increasing their fees as a result of external force of the market and hence as in the case of increase in noninterest income, rarely interest income can be observed independent of variable income, fixed income and/or finance structure. Until 1990s it was widely accepted that income sources of banks were directed towards intermediary based activities and price based financial instruments and services were decreasing income of banks through volatility diversification of bank income. However, empirical studies conducted in recent years have not provided results confirming this understanding.

In literature studies made on banks, mostly determinants of bank profitability and bank performance (e.g. Athanasoglu et al., 2005; Kosmidou et al., 2006; Sayilgan \& Yildirim, 2009; Ramlall, 2009) have been emphasized. There is quite limited studies on the relation between noninterest income of the banks and performance. In one of such research studies on US banking system, De Young \& Rice (2004) have shown that features of banks, market conditions and technological advancements are related to increase in noninterest income of banks. Besides, they have attempted to construct two different models in the way of showing relation between increase in variety of noninterest income and better or worse financial performance. In the research in question, it has been concluded that larger banks earn more noninterest income and better managed banks give less importance to noninterest income. In addition to these results, some other results have been obtained such as 
some technological developments like mutual funds increase noninterest income, some other technological developments like credit securitization decrease noninterest income of the banks. In their research they obtained findings showing that marginal increase in noninterest income is related to profitability.

In another study which they did for Caribbeans, Craigwell \& Maxwell (2005) researched noninterest tendencies of commercial banks and determinants of noninterest income of banks in Barbados banking system. In their research they have reached the conclusion that bank characteristics and ATM technologies are the most important determinants of noninterest income levels of banks. They also have reached the conclusion that increase in noninterest income is related to bank profitability and change in the profitability.

Inspired by the study of De Young \& Rice (2004) Kim \& Kim (2010) have conducted a research on South Korean banking system and found relations between noninterest income and bank characteristics, market conditions and technological developments as well as between noninterest income and financial performance of banks.

All of the above mentioned studies are studies related to commercial banks which are also called conventional banks. As mentioned earlier, one can hardly find research studies on relations between noninterest income and performance at the Islamic banks which find an important space for themselves within the banking system in recent years. In a research conducted by Shahimi et al. (2006) for Islamic banks in Malaysia, bank characteristics that impact the development in nontraditional bank activities have been analyzed. This study is important one from the perspective of relation between nonprofit income. Other than this study in the studies on Islamic banking generally basic determinants of bank profitability (e.g. Bashir, 2000; Hassan \& Bashir, 2003; Al-Kassim, 2005; Haron \& Azmi, 2004; Karim et al., 2010; Smaoui \& Salah, 2011) and bank performance (e.g. Masruki et al., 2010; Ashraf \& Rehman, 2011; Jaffar \& Manarvi, 2011; Ansari \& Rehman, 2011, Hanif et al., 2012) including nonprofit income have been the subject matter of the analysis.

In this study on the other hand, the relation between noninterest (nonprofit) income and performance of commercial and participation banks which are active in Turkish banking system has been analyzed. Within this context, the potential impact of increasing noninterest (nonprofit) income level on financial performances of commercial and participation banks is discussed.

\section{Data and Methodology}

The data used in the analysis of this study comprise the 6 years data set between 2005 and 2010. The study comprises of 30 banks, 26 of which are commercial banks and 4 participation banks whose uninterrupted data were available for the analysis period. For each variable in the date set there are 180 observations comprised of 30 banks and 6 years. The date pertaining to commercial banks have been taken from The Bank Association of Turkey internet website. Participation banks' data on the other hand have been received from website of Association of Turkish Participation Banks. Due to the fact the noninterest banks actively operating in Turkey have started their activities in 2005 and as of the date this research was conducted 2011 financials were not available the analysis period has been determined as the period between 2005-2010.

Table 1. Descriptions of variables

\begin{tabular}{lll}
\hline Dependent Variables & & Descriptions \\
\hline \multirow{3}{*}{ Profitability ratiost } & Return on Assetst & Ne Profit / Total Assets \\
& Return on Equityt & Net Profit / Equity \\
& Noninterest (Nonprofit) Income Marjint & Noninterest (Nonprofit) Income / Total Assets \\
\hline Independent Variables & & Descriptions \\
\hline Capital Adequacyt-1 & Equity Ratio t-1 & Equity / Total Assets \\
\hline \multirow{2}{*}{ Overheads t-1 } & Overheads / Operating Expenses t-1 & Overheads / Total Operating Income \\
& Real Overheads t-1 (Million TL) & Real overheads compared to 2005 \\
\hline \multirow{2}{*}{ Loans t-1 } & Reserves / Loans t-1 & Loan Loss Reserves / Total Loans \\
& Loans / Total Assets t-1 & Total Loans / Total Assets \\
\hline \multirow{3}{*}{ Size t-1 } & Number of Employees t-1 & The number of bank employees \\
& Share of Industry t-1 & Total Bank Assets / Total Industry Assets \\
\hline Participation Bankt & Reel Total Assets t-1 (Million TL) & Real total assets compared to 2005 \\
\hline
\end{tabular}

The variables of the study are shown in Table 1. Profitability rate of banks are explicated from different angles with three dependent variables. The noninterest (nonprofit) income margin which is one of the dependent variables has been calculated as the rate of noninterest income to assets for commercial banks and nonprofit 
income to assets for participation banks. In order to explain the impact of capital adequacy, overheads, loans, size and type of bank on each of these three different profitability rates there are eight independent variables in the study. With this study, direction and extent of impacts on profitability rates of independent variables that represent said five dimensions of banks in question are displayed. In the models constructed effect of previous year's independent variables on following year's dependent variable is analyzed. Therefore in all models it is assumed that independent variables of current year have an effect on dependent variables of following year. In this assumption there are two exceptions. Firstly, participation banks dummy variable which is an independent variable is being included in the models at the same period as dependent variables. Secondly, as an independent variable effect of noninterest (nonprofit) income margin on asset and equity capital profitability is analyzed for the same period.

The data in data analysis are in three forms namely, cross sectional, time series and panel. Among them the cross sectional data shows the situation of a variable for certain units at a given time. In other words it reflects instantaneous situation. Time series shows the trend of a variable over time with respect to a unit. Panel data on the other hand demonstrates the common trend of a variable with respect to units and time (Baltagi, 2005; Kennedy, 2006). Because panel data in question contain more information about variables they have superiority over other date sets. Because of these superior characteristics researchers heavily prefer panel date analysis (Hsiao, 2003). General framework for panel data can be illustrated as the following:

$$
y_{i t}=\alpha+\sum_{k=1}^{K} \beta_{k} x_{k i t}+u_{i t} \quad \mathrm{i}=1, \ldots \mathrm{N}, \mathrm{t}=1, \ldots \ldots . \mathrm{T}
$$

Here $u$ represents error term, $t$ represents time and i represents unit. In this approach, because unit and time dimensions of combined data are ignored the Least Square (LS) regression is employed in the forecast (Brooks, 2008; Johnston \& Dinardo, 1997). Here if there is different variance problem with the data then adjustments should be made (Wooldridge, 2003).

The coefficients calculated in panel data analysis take up different values for different units (i's) and for different time periods (t's). Therefore a decrease is observed in the degree of freedom which gives the relation between number of coefficients to be forecast and number of observations. To overcome this problem calculation models that have different assumptions in regards to characteristics of terms and variability of the coefficients are used. Among them fixed effects model and random effects model are most frequently used ones.

In fixed effects model for each cross sectional unit a different fixed coefficient is allowed to be gained. Fixed effects model assumes that differences stem from fixed term of the model. Therefore it tries to capture this difference with differences in the fixed terms. This way, in order to capture this difference fixed coefficients are added to the model. General form of the fixed effects models can be presented as follows (Hsiao, 2003):

$$
y_{i t}=\alpha_{1}+\alpha_{2} D_{2 i}+\ldots+\alpha_{N} D_{N N}+\beta_{1} x_{1 i t}+\beta_{2} x_{2 i t}+\ldots+\beta_{k} x_{k i t}+u_{i t} \quad \mathrm{i}=1, \ldots, \mathrm{N} \text { ve } \mathrm{t}=1, \ldots, \mathrm{T}
$$

In this equation; yit represents the dependent variable and xit represents the vector formed by $\mathrm{k}$ number independent explanatory variables. $\alpha \mathrm{i}(\mathrm{i}=1,2, \ldots, \mathrm{N})$ is the model constant specific to analyzed unit. Ds are dummy variables aiming at capturing the fixed effects between units. $\beta$, on the other hand is coefficients vector reflecting inclination coefficients of each of explanatory variables. If the assumption that these dummy variables in the model are not homogenous, meaning that they are different is accepted then fixed effects is preferred. In opposite situation the LS calculated with combined variables is preferred.

The random effects model which is another method used in panel data model forecasts is used when the units are randomly taken from a large mass (Grene, 1997). The general form of random effect model can be described as follows (Öztürk, 2011):

$$
y_{i t}=\alpha+\sum_{k=1}^{K} \beta_{k} x_{k i t}+\varepsilon_{i t} \quad \mathrm{i}=1, \ldots, \mathrm{N} \text { ve } \mathrm{t}=1, \ldots, \mathrm{T}
$$

In the equation; $\varepsilon i t=\mu i+v i t$ it reflects the decomposing effects of error components. The effects specific to explanatory variables $(\mu \mathrm{i})$ are distributed randomly and normally. On the other hand, the remainders which express all the explanatory variables (vit) distribute normally as well. Forecast of the model is done through Generalized Least Squares (GLS) method. At the first phase convergent forecast of $\sigma_{\mu}^{2}$ and $\sigma_{v}^{2}$ variances are made. Following this forecast with LS is performed.

An agreed upon statistical test or definite rule has not yet been determined regarding which of fixed effect and random effect model will be used. In the decision regarding which one will be preferred usually desired 
inference has more influence. And this is dependent on the sample being worked on. If the data is taken from a closed sample or it is comprised of certain group of people or certain region then fixed effect model is more appropriate. If the data is randomly taken from a large mass by sampling then in this case random effect model can be seen as a more appropriate decision (Swamy \& Mehta, 1977; Öztürk, 2011). As mentioned earlier, although there is no agreed upon statistical test in regards to which model to prefer in practice Hausman test is frequently used in comparison of models.

In this study, because all of the mass has been included in the sampling random effects model has not been preferred. For the combined data LS and fixed effects model have been used in the calculations.

\section{Findings and Discussion}

The findings derived from the research are presented below under two headings for general characteristics of variables and panel data analysis forecasts.

\subsection{General Characteristics of Variables}

Descriptive statistics and correlation coefficients of asset profitability, equity capital profitability and noninterest (nonprofit) income margin, which are dependent variables of the study are presented in Table 2. According to the table, on average sample's asset profitability is over $2 \%$, equity capital profitability is over $11 \%$ and noninterest (nonprofit) income margin is over $11 \%$. This situation shows that in the periods in question banks were profitable and profitability was high particularly from the equity capital perspective. On the other hand it is observed that divergence from average of profitability in question are high. As a result, calculation of minimum values of profitability as negative, maximum values as high positive and median value as higher than average makes clear that profitability for all the banks in sampling was not at similar levels. As expected, correlation coefficients among profitability variables are positive and statistically significant. Particularly the correlation between asset profitability and equity profitability is high.

Table 2. Descriptive statistics and correlation coefficients of dependent variables

\begin{tabular}{llllllll}
\hline & Minimum & Median & Maximum & Mean & St. Dev. & ROA & ROE \\
\hline Return on Assets (ROA) & -0.1255 & 0.0186 & 0.5239 & 0.0213 & 0.0439 & 1 & \\
Return on Equity (ROE) & -1.7863 & 0.1489 & 0.3409 & 0.1194 & 0.1988 & $0.3525^{* * *} 1$ & 1 \\
Noninterest (Nonprofit) Income Marjin & -0.0340 & 0.0217 & 0.4397 & 0.0287 & 0.0413 & $0.1471^{*}$ & $0.1323^{*}$ \\
\hline
\end{tabular}

Note: ${ }^{*}$ and $* * *$ show the statistical significance levels at 0.10 and 0.01 respectively.

In the Table 3 below descriptive statistics of independent variables are presented. When one looks at indicator for equity adequacy rather than capital adequacy the capital adequacy rate of banks is approximately $15 \%$. It is understood that this rate's variation among banks is higher than minimum, maximum and standard deviation values. Form the table it is seen that banks' overheads are half of operational profits, similarly that loans granted are close to half of asset total, that provisions kept for loans are $4 \%$ of loans and that the rate of bank asset total, which is one of the bank size indicators, to sector assets total is $3 \%$. Another size indicator number of employees is 5.209 and real asset amount is 15.913 million TL. And bank real overheads is 454 million TL. In light of the foregoing, it can be said that on average banks' overheads are not high, loans are at high level and there is low provision for loans. From the size perspective it can be stated that banks are larger compared to the restructuring period of the sector. As seen in Table 2, it can be observed that these indicators are not homogenous from the perspective of banks. And this shows that banks have different characteristics and they adopt different policies in similar matters.

Table 3. Descriptive statistics of independent variables

\begin{tabular}{lllllll}
\hline \multicolumn{2}{l}{ Independent Variables } & Minimum & Median & Maximum & Mean & St. Dev. \\
\hline \multirow{2}{*}{ Capital Adequacy } & Equity Ratio (ER) & 0.0001 & 0.1235 & 0.6597 & 0.1480 & 0.0915 \\
\multirow{2}{*}{ Overheads } & Overheads / Operating Income (OOP) & 0.029070 & 0.4991 & 0.9666 & 0.4881 & 0.1892 \\
& Real Overheads (RO) (Million TL) & 0.0248 & 129 & 4700 & 454 & 764 \\
\hline \multirow{2}{*}{ Loans } & Reserves / Loans (RL) & 0.002 & 0.0188 & 0.6048 & 0.0401 & 0.0649 \\
& Loans / Total Assets (LTA) & 0.0028 & 0.5361 & 0.8188 & 0.4846 & 0.2048 \\
\hline \multirow{2}{*}{ Size } & Number of Employees (NE) & 15 & 2332 & 23944 & 5209 & 6212 \\
& Share of Industry (SI) & 0,0001 & 0.0083 & 0.1704 & 0.0339 & 0.0492 \\
& Total Assets (TA) (Million TL) & 0.4883 & 3943 & 93607 & 15913 & 23596 \\
\hline
\end{tabular}


In Table 4 correlation coefficients between independent variables are presented. While showing the relation levels among variables the correlation coefficients can also point to the problem of high multi collinear relation among the independent variables that will be used in the model. In this context, in case there is high correlation among more than one independent variables which represent the same characteristic these variables cannot be provided in the same equation. Instead they should be treated in different equations. When looked at Table 3 it is seen that this multi collinearity problem exists for size indicators. Accordingly, real asset total, share of bank asset size in the sector and number of employees, which are size indicators not to be employed within the same model.

Table 4. Correlation coefficients of dependent variables

\begin{tabular}{|c|c|c|c|c|c|c|c|c|}
\hline \multicolumn{2}{|c|}{ Dependent Variables } & \multirow{2}{*}{$\begin{array}{l}\text { ER } \\
1 \\
\end{array}$} & \multirow[t]{2}{*}{ OOP } & \multirow[t]{2}{*}{ RO } & \multirow[t]{2}{*}{ RL } & \multirow[t]{2}{*}{ LTA } & \multirow[t]{2}{*}{$\mathrm{NE}$} & \multirow[t]{2}{*}{ SI } \\
\hline Capital Adequacy & Equity Ratio & & & & & & & \\
\hline \multirow{2}{*}{ Overheads } & Overheads / Operating Income & 0.055 & 1 & & & & & \\
\hline & Real Overheads (Million TL) & $-0.204 * * *$ & -0.058 & 1 & & & & \\
\hline \multirow[b]{2}{*}{ Loans } & Reserves / Loans & $0.288 * * *$ & 0.081 & -0.067 & 1 & & & \\
\hline & Loans / Total Assets & $-0.365 * * *$ & -0.083 & -0.007 & $\begin{array}{l}-0.531 * * \\
*\end{array}$ & 1 & & \\
\hline \multirow{3}{*}{ Size } & Number of Employees & $-0.330 * * *$ & $0.355 * * *$ & $0.768 * * *$ & -0.144 & 0.056 & 1 & \\
\hline & Share of Industry & $-0.263^{* * *}$ & $0.299 * * *$ & $0.772 * * *$ & -0.102 & -0.037 & $0.948 * * *$ & \\
\hline & Total Assets (Million TL) & $-0.275^{* * *}$ & $0.337 * * *$ & $0.771 * * *$ & -0.124 & -0.018 & $0.964 * * *$ & $0.966 * * *$ \\
\hline
\end{tabular}

Note: $* * *$ show the statistical significance level at 0.01 . The bold correlation coefficients indicate the high relation between sub factors of the same characteristics.

On the other hand, the correlation between equity capital rate meaning capital adequacy and size indicators, loan rate, loan provision rate and overheads is negative. This means that small banks have higher capital adequacy, they adopt tighter loan policy and their expenses is less. There is a positive significant correlation between banks' overheads and their sizes. This finding shows that large banks naturally assume higher overheads. On the other hand, Table 4 shows that correlation between share of loans in assets and rate of provisions to loans is negative and significant.

\subsection{Panel Data Analysis Findings}

Before the panel data analysis stationarity of data should be searched and later panel data analysis should be made with stationary data. Therefore, below panel stationarity test has been made first and later panel data analysis is performed.

\subsubsection{Panel Stationarity Test Findings}

Before moving to panel data analysis it is necessary to check whether all the variables are stationary or not. Because a model constructed with non-stationary data set is forecasted with LS method, after a shock it is possible to get results that actually do not exist between variables. And this leads to the problem called spurious regression (Sims, 1980). Thus for the analysis whether each variable is stationary or not should be determined. In order to secure stationarity unit root tests should be performed. Non-stationary variables are excluded from the analysis and the data analysis is performed only with the variables whose stationarity have been determined. To this end in this study Levin, Lin and Chu (LLC) unit root test has been used for stationarity analysis. In the application of this test, to determine the most appropriate delay length Scwarz Information Criterion (SIC) is mostly preferred. In the test of LLC unit root, in H0 hypothesis if the variable contains unit root is tested. If the coefficient is significantly different from zero it is accepted that the series in question does not contain unit root and it is stationary at its original level. The original level of the variables which are not stationary at first-order level is taken and stationary test is performed (Yamak et al., 2007). This process is repeated until the level which does contain unit root, meaning stationary is reached.

In the table it is seen that all of the dependent variables and independent variables except real asset total which is one of the size variables do not contain unit root at its original levels. Therefore variables except for the real asset total are stationary at their original levels. Variables that are found to be stationary at its level will be used in the panel data analysis forecast. Because real asset total variable is not stationary it will not be employed in the analysis. This way, three dependent variables all of which are stationary at the original level and seven independent variables are included in the calculations to be made. And this will eliminate the probability of existence of spurious regression in the analysis. By doing so, through the panel data analysis models to be forecasted, an attempt will be made to show the effect of size, equity capital, overheads and loans on 
performance of commercial and participation banks in the sampling.

Table 5. Levin, Lin ve Chu (LLC) unit root test of variables

\begin{tabular}{llll}
\hline Dependent Variables & & $\mathrm{t}$ statistics & Decision \\
\hline \multirow{2}{*}{ Profitability ratiost } & Return on Assets & $-3,514^{* * *}$ & Stationary \\
& Return on Equity & $-30,334^{* * *}$ & Stationary \\
& Noninterest (Nonprofit) Income Marjin & $-2,607^{* * *}$ & Stationary \\
\hline \multirow{2}{*}{ Independent Variables } & & $\mathrm{t}$ statistics & Decision \\
\hline \multirow{2}{*}{ Size } & Log(Real Total Assets) & 0,019 & Non-stationary \\
& Industry Share of Total Assets & $-13,390^{* * *}$ & Stationary \\
\hline \multirow{2}{*}{ Capital Adequacyt-1 } & Log(Number of Employees) & $-57,692^{* * *}$ & Stationary \\
\hline \multirow{2}{*}{ Overheads } & Equity Ratio & $-48,184^{* * *}$ & Stationary \\
& Overheads / Operating Income & $-9,647^{* * *}$ & Stationary \\
\multirow{2}{*}{ Loans } & Log(Real Overheads) & $-3,019^{* * *}$ & Stationary \\
& Reserves / Loans & $-6,954^{* * *}$ & Stationary \\
\hline
\end{tabular}

Note: $* * *$ show the statistical significance level at 0.01 .

\subsubsection{Return on Asset Ratio Findings}

Table 6 below shows the solution for banks' asset profitability models with combined data. The fact that $\mathrm{F}$ statistics of all models in the table are significant in all models indicates that the relation between independent variables and asset profitability is linear. In this linear relation it is seen that models are able to explain $7 \%$ of the total change in asset profitability. The test values performed in regards to importance of year fixed effect on asset profitability have not been significant. This result shows that in explaining the asset profitability the effect of year difference, meaning time is not significant. From here it becomes evident that fixed effects model should not be employed for asset profitability and it would be more appropriate to make forecasts and comments in accordance with LS using combined data.

Table 6. The panel data analysis findings of return on assets

\begin{tabular}{|c|c|c|c|c|c|}
\hline Independent Variables & Expected Sign & Basic Model & Share of Industry & Number of Employess & Overheads \\
\hline Constant & & 0,0061 & $-0,0038$ & $-0,0069$ & $-0,0060$ \\
\hline Return on Equityt-1 & + & $0,1489 *$ & $0,1635^{*}$ & $0,1693^{*}$ & $0,1689^{*}$ \\
\hline Overheads / Operating Incomet-1 & - & 0,0008 & 0,0018 & 0,0014 & \\
\hline Loans / Total Assetst-1 & + & $-0,010$ & $-0,0073$ & $-0,0088$ & $-0,0009$ \\
\hline Reserves / Loanst-1 & + & $-0,0001$ & $-0,0024$ & $-0,0012$ & $-0,0013$ \\
\hline Participation Bank Dummyt & + & $0,0197 * *$ & $0,0221 * *$ & $0,0228 * *$ & $0,0228 * *$ \\
\hline Share of Industryt-1 & + & & $0,0886^{* *}$ & & \\
\hline Log(Number of Employeest-1) & + & & & $0,0001 * *$ & $0,0001^{*}$ \\
\hline Log(Real Overheadst-1) & - & & & & $-0,0001$ \\
\hline $\mathrm{R} 2$ & & 0,1013 & 0,1084 & 0,1106 & 0,1106 \\
\hline Adjusted R2 & & 0,0701 & 0,0709 & 0,0733 & 0,0733 \\
\hline F Statistic & & $3,2452 * * *$ & $2,8963 * *$ & $2,9643^{* * *}$ & $2,9637 * * *$ \\
\hline \multicolumn{6}{|c|}{ Year Fixed Effects Model Results of Return on Assets } \\
\hline & & Basic Model & Share of Industry & Number of Employess & Overheads \\
\hline $\mathrm{X} 2$ & & 2,5743 & 2,8599 & 3,3276 & 3,3412 \\
\hline
\end{tabular}

Note: *,** and $* * *$ show the statistical significance levels at $0.10,0.05$ and 0.01 respectively.

When one looks at the results of the models in Table 6, it has been observed that according to the basic model, capital adequacy and bank's being a participation bank has positive significant effect on bank profitability. On the other hand it has been found that effect of other independent variables on asset profitability is not significant and the effect is random. Following this, according to two models where size variables sector share and number of employees are added to the basic model, it has been determined that both size indicators have positive and significant effect on asset profitability. In the last model forecasted for asset profitability, it has been concluded that effect of overheads on asset profitability is not significant.

These findings show that asset profitability continues higher at the banks with higher capital adequacy and larger size. Moreover, it is observed that asset profitability of participation banks are higher than those of commercial banks. Hence, for the large banks that have higher capital adequacy in previous year asset profitability can be 
higher in the following year. And this shows that for the large banks with stronger capital structure in the previous year asset profitability in the following year is higher. Consequently, it can be claimed that though the activities with strong capital structure meaning high equity capital with less borrowed funds, less interest is paid and the competitive advantage gained by being large increases the next period asset profitability. In addition to these, the fact that asset profitability of participation banks are found to be higher than commercial banks might be the result of having few participation banks. Because the number of banks active in participation banking is four. The competition among these few participation banks is expected to be lower than the competition among commercial banks whose number is 26 . Therefore asset profitability of the participation banks is realized to be higher.

\subsubsection{Return on Equity Capital Ratio Findings}

The solution of equity capital profitability models with combined data is presented in Table 7 . According to the table $\mathrm{F}$ statistics of all models are significant. It is seen that independent variables are able to explain in the range of $13 \%$ to $30 \%$ of total change in the rate on equity capital ratio. Test values conducted in regards to importance of effect of years on equity capital have not been found significant. Hence in explaining the equity capital profitability time fixed effect is not important. Therefore for the return on equity capital ratio fixed effects model is not preferred. It becomes clear that it is more appropriate to make equity capital profitability forecasts and comments in accordance with LS.

Table 7. The panel data analysis findings of return on equity

\begin{tabular}{|c|c|c|c|c|c|}
\hline Independent Variables & Expected Sign & Basic Model & Share of Industry & Number of Employess & Overheads \\
\hline Constant & & 0.0643 & -0.0602 & -0.0957 & -0.1378 \\
\hline Return on Equityt-1 & + & 0.1198 & 0.3028 & $0.3697 *$ & $0.4027 * *$ \\
\hline Overheads / Operating Incomet-1 & - & $-0.1768 * * *$ & $-0.0989 * *$ & -0.0606 & \\
\hline Loans / Total Assetst-1 & + & $0,2334^{*}$ & $0.2667 * *$ & $0.2481 * *$ & $0.2523^{* *}$ \\
\hline Reserves / Loanst-1 & + & 0,2307 & $0.2752 *$ & $0.2589^{*}$ & $0.2667^{*}$ \\
\hline Participation Bank Dummyt & + & 0,0242 & $0.0548 * *$ & $0.0625 * * *$ & $0.0630 * * *$ \\
\hline Share of Industryt-1 & + & & $1.1081 * * *$ & & \\
\hline Log(Number of Employeest-1) & + & & & $0,0001 * * *$ & $0,0001 * * *$ \\
\hline $\log ($ Real Overheadst-1 $)$ & - & & & & $-0,0001 * * *$ \\
\hline $\mathrm{R} 2$ & & 0,1625 & 0,2746 & 0,3051 & 0,3227 \\
\hline Adjusted R2 & & 0,1335 & 0,2441 & 0,2759 & 0,2943 \\
\hline F Statistic & & $5.5895 * * *$ & $9,0199 * * *$ & $10,4641 * * *$ & $11,3572 * * *$ \\
\hline \multicolumn{6}{|c|}{ Year Fixed Effects Model Results of Return on Equity } \\
\hline & & Basic Model & Share of Industry & Number of Employess & Overheads \\
\hline $\mathrm{X} 2$ & & 8,8047 & 7,9097 & 8,1198 & 4,6088 \\
\hline
\end{tabular}

Note: $* * *$ and $* * *$ show the statistical significance levels at $0.10,0.05$ and 0.01 respectively.

When one has closer look at the results of models in Table 7, according to the basic model it is determined that overheads have negative effect while loans have positive significant effect on bank equity capital profitability. The effects of other independent variables on equity capital profitabiliy are not significant. Following this, in the model where sector share as size variable is included into the basic model, it has been observed that sector share and participation bank dummy variable have positive and significant effect on equity capital profitability. It has been concluded that in addition to positive significant effect of number of employees and real overheads variables that are included in the last two forecasted models capital adequacy has positive significant effect, as well. Besides, independent variables included into basic model and particularly size among them have considerably increased the explanatory power of equity capital profitability.

According to these findings, equity capital profitability of the banks are higher for the banks which have higher capital adequacy and loans, which have low overheads and which are larger in size. In addition to this, equity capital profitability of participation banks are higher than commercial banks. Therefore, equity capital profitability of the large banks which have high capital adequacy, larger loan portfolio and which control overheads in previous year are higher in the following year.

Thus it can be said that the banks which pay less interest due to strong capital structure, which can benefit from competition advantage stemming from large size, which can make savings in the expenses increase equity capital profitability in the following year. Along with all these, equity capital profitability of the participation banks have been found higher than commercial banks. And this, as in the case of abovementioned asset profitability, can be linked to the scarcity of participation banks in number. Because the competition among fewer 
participation banks can be lower than the competition among commercial banks which are more in number, equity capital profitability of participation banks have been realized higher.

\subsubsection{Noninterest (Nonprofit) Income Margin Findings}

Outputs of combined data for noninterest (nonprofit) income margin models are presented in Table 8 . The $\mathrm{F}$ statistics in all models are significant and $23 \%$ of total change in noninterest (nonprofit) income margin is explained in the models. The test values conducted in regards to importance of fixed effects of years on noninterest (nonprofit) income margin have not been found significant. This result shows that in explaining noninterest (nonprofit) income margin the difference in years is not important. From this, it is concluded that for noninterest (nonprofit) income margin fixed effects model should not be preferred, and it would be more appropriate to make the forecasts and comments in accordance with LS which uses combined data.

When one looks closer to the Table 8 , it is observed that according to the basic model capital adequacy and provision's rate to loans have positive and significant effect on noninterest (nonprofit) income margin. The effect of other independent variables on noninterest (nonprofit) income margin have not been significant. Following this, in the three constructed models where size and real overheads variables are added to the basic model it has been concluded that only participation banks dummy variable have positive and significant effect on noninterest (nonprofit) income margin.

This finding shows that following period noninterest (nonprofit) income margins of the banks which pay less interest due to strong capital structure and which have higher loan provision rate are increasing. Moreover, it has been concluded that noninterest (nonprofit) income margin of participation banks are higher than commercial banks. As in the case of abovementioned asset profitability and equity capital profitability, this can be linked to the scarcity of participation banks in number. Because the competition among participation banks which are few in number can be lower, non-dividend income margin of participation banks might have been realized higher than noninterest income margin of commercial banks.

Table 8. The panel data analysis findings of noninterest (nonprofit) income margin

\begin{tabular}{|c|c|c|c|c|c|}
\hline Independent Variables & Expected Sign & Basic Model & Share of Industry & Number of Employess & Overheads \\
\hline Constant & & -0.0061 & -0.0129 & -0.0150 & -0.0123 \\
\hline Return on Equityt-1 & + & $0.0892 * *$ & $0.0993 * *$ & $0.1031 * *$ & $0.1014 * *$ \\
\hline Overheads / Operating Incomet- 1 & - & -0.0025 & 0.0017 & 0.0039 & \\
\hline Loans / Total Assetst-1 & + & 0.0222 & 0.0240 & 0.0230 & 0.0225 \\
\hline Reserves / Loanst-1 & + & $0.1731 * *$ & $0.1755^{* *}$ & $0.1746^{* *}$ & $0.1745^{* *}$ \\
\hline Participation Bank Dummyt & + & 0.0066 & $0.0083 * *$ & $0.0088 * *$ & $0.0088^{* *}$ \\
\hline Share of Industryt-1 & & & 0.0611 & & \\
\hline Log(Number of Employeest-1) & + & & & 0,0001 & 0,0001 \\
\hline $\log ($ Real Overheadst-1) & - & & & & $-0,0001$ \\
\hline $\mathrm{R} 2$ & & 0,2493 & 0,2580 & 0,2606 & 0,2608 \\
\hline Adjusted R2 & & 0,2233 & 0,2269 & 0,2296 & 0,2298 \\
\hline F Statistic & & $9,5678 * * *$ & $8,2885^{* * *}$ & $8,4028 * * *$ & $8,4110^{* * *}$ \\
\hline \multicolumn{6}{|c|}{ Year Fixed Effects Model Results of Noninterest (Profit) Income Margin } \\
\hline & & Basic Model & Share of Industry & Number of Employess & Overheads \\
\hline $\mathrm{X} 2$ & & 6.4635 & 6.8416 & 6.8762 & 8.0700 \\
\hline
\end{tabular}

\subsubsection{Effect of Noninterest (Nonprofit) Income Margin on Bank Performance}

Here, effect of independent variable noninterest (nonprofit) income margin on return on asset and equity capital ratios that stand in the above models have been discussed. In the Table 9 and 10 below the findings reached are presented. Table 9 shows that noninterest (nonprofit) income margin does not have statistically significant effect on asset profitability. This finding indicates that effect of noninterest (nonprofit) income on asset profitability of banks is a random result.

According to the finding in Table 10, it is seen that noninterest (nonprofit) income margin has statistically significantly increased the equity capital profitability and considerably increased the explanatory power of the model. This finding makes clear that noninterest (nonprofit) income margin increases equity capital profitability. Consequently, it can be said that equity capital profitability meaning shareholder profitability of the banks which have high noninterest (nonprofit) income is considerably higher. 
Table 9. The panel data analysis findings of return on assets

\begin{tabular}{|c|c|c|c|c|c|}
\hline Independent Variables & Expected Sign & Basic Model & Share of Industry & Number of Employess & Overheads \\
\hline Constant & & 0.0061 & -0.0042 & -0.0074 & -0.0064 \\
\hline Return on Equityt-1 & + & 0.1495 & 0.1659 & 0.1722 & 0.1718 \\
\hline Overheads / Operating Incomet-1 & - & -0.0081 & -0.0018 & 0.0015 & \\
\hline Loans / Total Assetst-1 & + & -0.0099 & -0.0068 & -0.0082 & -0.0085 \\
\hline Reserves / Loanst-1 & + & $-0,0001$ & 0.0065 & 0.0062 & 0.0063 \\
\hline Noninterest (Nonprofit) Income Margint & + & -0.0063 & -0.0233 & -0.0287 & -0.0282 \\
\hline Participation Bank Dummyt & + & $0.0197 * *$ & $0.0223 * *$ & $0.0230^{* *}$ & $0.0231 * *$ \\
\hline Share of Industryt-1 & + & & $0.0900 *$ & & \\
\hline Log(Number of Employeest-1) & + & & & $0,0001 *$ & $0,0001 * *$ \\
\hline Log(Real Overheadst-1) & - & & & & $-0,0001$ \\
\hline $\mathrm{R} 2$ & & 0.1013 & 0.1085 & 0.1109 & 0.1108 \\
\hline Adjusted R2 & & 0.0636 & 0.0646 & 0.0670 & 0.0669 \\
\hline F Statistic & & $2.6859 * *$ & $2.5291 * *$ & $2.5290 * *$ & $2.5285^{* *}$ \\
\hline
\end{tabular}

Note: $* * *$ and $* * *$ show the statistical significance levels at $0.10,0.05$ and 0.01 respectively.

Table 10. The panel data analysis findings of return on equity

\begin{tabular}{|c|c|c|c|c|c|}
\hline Independent Variables & Expected Sign & Basic Model & Share of Industry & Number of Employess & Overheads \\
\hline Constant & & 0.0739 & -0.0423 & -0.0758 & -0.1213 \\
\hline Return on Equityt-1 & + & -0.0209 & 0.1653 & 0.2327 & 0.2663 \\
\hline Overheads / Operating Incomet-1 & - & $-0.1728 * * *$ & $-0.1014 * *$ & -0.0658 & \\
\hline Loans / Total Assetst-1 & + & $0.1983^{*}$ & $0.2334 * *$ & $0.2175^{* *}$ & $0.2219 * *$ \\
\hline Reserves / Loanst-1 & + & -0.0424 & 0.0322 & 0.0269 & 0.0320 \\
\hline Noninterest (Nonprofit) Income Margint & + & $1.5776^{* *}$ & $1.3845^{* *}$ & $1.3282 * *$ & $1.3452 * *$ \\
\hline Participation Bank Dummyt & + & 0.01370 & $0.0433 *$ & $0.0508 * *$ & $0.0512 * *$ \\
\hline Share of Industryt-1 & + & & $1.0234 * * *$ & & \\
\hline Log(Number of Employeest-1) & + & & & $0,0001 * * *$ & $0,0001 * * *$ \\
\hline Log(Real Overheadst-1) & - & & & & $-0,0001 * * *$ \\
\hline $\mathrm{R} 2$ & & 0.2361 & 0.3306 & 0.3565 & 0.3754 \\
\hline Adjusted R2 & & 0.2041 & 0.2976 & 0.3248 & 0.3446 \\
\hline F Statistic & & $7.3669 * * *$ & $10.0172 * * *$ & $11.2370 * * *$ & $12.1927 * * *$ \\
\hline
\end{tabular}

Note: $* * *$ and $* * *$ show the statistical significance levels at $0.10,0.05$ and 0.01 respectively.

As a result, it has been found that noninterest (nonprofit) income has effect on bank performance. It has been determined that although this effect has increased profitability of the banks' shareholders it has no effect on profitability of the circles providing funds to the banks. From this point of view, it can be said that noninterest (nonprofit) incomes are transferred only to bank shareholders. Hence, banks do not share their noninterest (nonprofit) incomes with the circles who provide funds. Naturally, it becomes evident that they share interest (profit) incomes with these circles.

\section{Conclusion}

The traditional role of commercial and Islamic banks has centered on intermediation and the generation of net interest or profit income through two core activities; namely, the collection of deposits on which banks pay interest or profit and the issuing of loans for which they receive interest or profit income. Over the years, however, commercial and Islamic banks, especially in the developed countries, have gradually expanded beyond their traditional role and sources of income to encompass more activities that generate noninterest or nonprofit income. This article explores the possibility. We estimate an econometric model for Turkish commercial and participation (Islamic) banks between 2005 and 2010. The model analyzes (a) which bank characteristics have been most closely associated with the increases in various types of noninterest or nonprofit income at Turkish commercial and participation banks, and (b) whether increases in various types of noninterest or nonprofit income have been associated with improved or worsened bank financial performance. The conclusions reached in this study can be summarized as follows:

1. Capital adequacy and bank size increases asset profitability. Besides asset profitability of participation banks is higher than that of commercial banks. This leads to the conclusion that banks and participation banks which have adequate capital and which are large in size gain higher profits from their assets.

2. Capital adequacy and size of the bank increase the asset profitability as well as equity capital profitability. In 
addition to this, like asset profitability, equity capital profitability of participation banks are higher than commercial banks. On the other hand, it has been concluded that equity capital profitability of the banks which grant more loans and make savings on overheads continue higher.

3. As in the case of increasing asset and equity capital profitability, capital adequacy increases noninterest (nonprofit) income margin, as well. Besides, nonprofit income margin of participation banks is higher than noninterest income margin of commercial banks.

4. Noninterest (nonprofit) income margin increases equity capital profitability of banks.

As a conclusion, the fact that this study has been conducted with limited number of public data that affect bank performance and concentrated on a certain time period should be taken into account as a limiting factor when evaluating the results. Notwithstanding this, with this study it has emerged that in Turkish banking system along with capital adequacy, size, overheads, loan granting policies, being a participation bank has an effect on bank performance.

In the study it has been established that noninterest income which is the main revenue factor of commercial banks and nonprofit income which is the main revenue factor of participation banks have effect on equity capital profitability.

\section{References}

Al-Kassim, F. A. (2005). The profitability of islamic and conventional banking in the GCC countries: A comparative study. http://www.failaka.com/downloads/Profitability_Islamic_Banking.pd

Ansari, S., \& Rehman, A. (2011). Financial performance of islamic and conventional banks in Pakistan: A comparative study. 8th International Conference on Islamic Economics and Finance.

Ashraf, M. M., \& Rehman, Z. (2011). The performance analysis of islamic and conventional banks: the pakistan's perspective. Journal of Money, Investment and Banking, 22, 99-113.

Athanasoglu, P. P., Brissimis, S. N., \& Delis, M. D. (2005). Bank-specific, industry-specific and macroeconomic determinants of bank profitability, Bank of Greece. Working Paper, No. 25.

Baltagi, B. H. (2005). Econometric analysis of panel data. John Wiley\&Sons., Ltd., U.K.

Bashir, A. M. (2000). Determinants of profitability and rate of return margins in Islamic banks: Some evidence from the middle east. ERF's Seventh Annual Conference.

Brooks, C. (2008). Introductory econometrics for finance. New York: Cambridge University Press. http://dx.doi.org/10.1017/CBO9780511841644

Craigwell, R., \& Maxwell, C. (2005). Non-interest income and financial performance at commercial banks in the Caribbean. CBB Working Paper, 1-30.

De Young, R., \& Rice, T. (2004). Noninterest income and financial performance at U.S. commercial banks. The Financial Review, 39(1), 101-127. http://dx.doi.org/10.1111/j.0732-8516.2004.00069.x

Grene, W. H. (1997). Econometric analysis (3rd ed.). New Jersey: Prentice Hall.

Hanif, M., Tariq, M., Tahir, A., \& Momeneen, W. (2012). Comparative performance study of conventional and islamic banking in Pakistan. International Research Journal of Finance and Economics, 8, 62-72.

Haron, S., \& Azmi, W. N. (2004). Profitability determinants of islamic banks. Islamic Banking Conference, Union Arab Bank, Beirut, Lebnon.

Hassan, M. K., \& Bashir, A. M. (2003). Determinants of Islamic banking profitability. ERF Paper. http://nzibo.com/IB2/Determinants.pdf

Hsiao, C. (2003). Analysis of panel data. New York: Cambridge University Press. http://www.tkbb.org.tr/index.php?option=com_doqment\&cid=15\&Itemid=813

Jaffar, M., \& Manavri, I. (2011). Performance comparison of islamic and conventional banks in Pakistan. Global Journal of Management and Business Research, 11(1), 60-66.

Johnston, J., \& Dinardo, J. (1997). Econometric methods. New York: McGraw-Hill.

Karim, B. K., Sami, B. A., \& Hichem, B. K. (2010). Bank-specific, industry-specific and macroeconomic determinants of African islamic banks' profitability. International Journal of Business and Management Science, 3(1), 39-56.

Kennedy, P. (2006). Ekonometri kılavuzu. M. Sarımeşeli \& Ş. Açıkgöz (Trans.). Ankara: Gazi Kitabevi. 
Kim, J. G., \& Kim, Y. J. (2010). Noninterest income and financial performance at South Korea banks. http://www.apeaweb.org/confer/hk10/papers/kim_jingun.pdf

Kosmidou, K., Tanna, S., \& Pasiouras, F. (2006). Determinants of profitability of domestic UK commercial banks: Panel evidence from the period 1995-2002. Economic, Finance and Accounting, Applied Research Working Paper Series, 1-27.

Masruki, R., Ibrahim, N., Osman, E., \& Abdul Wahab, H. (2010). Financial performance of Malaysian islamic banks versus conventional banks. Journal of Business and Policy Research, 6(2), 67-79.

Özsoy, İ. (1997). Özel Finans Kurumları. İstanbul: Asya Finans Yayınları.

Öztürk , E. (2001). Parametrik olmayan ve parametrik panel veri modelleri: Çevresel kuznets eğrisinin analizi. (Unpublished PhD Thesis). Marmara Üniversitesi SBE.

Parlakkaya, R., \& Çürük, S. A. (2011). Using financial ratios to distinguish between participation and conventional banks: A case study of Turkey. Ege Academic Review, 11(3), 397-405.

Ramlall, I. (2009). Bank-specific, industry-specific and macroeconomic determinants of profitability in Taiwanese banking system: under panel data estimation. International Research Journal of Finance and Economics, 34, 160-167.

Sayilgan, G., \& Yildirim, O. (2009). Determinants of profitability in Turkish banking sector: 2002-2007. International Research Journal of Finance and Economics, 28, 207-214.

Shahimi, S., Ismail, A. G. B., \& Ahmad, S. B. (2006). A panel data analysis of fee income activities in islamic banks. Journal of King Abdulaziz University: Islamic Economics, 19(2), 22-36.

Sims, C. A. (1980). Macroeconomics and reality. Econometrica, 8(1), 1-48. http://dx.doi.org/10.2307/1912017

Smaoui, H., \& Salah, I. B. (2011). Profitability of islamic banks in the GCC region. Annual Paris Conference on Money, Economy and Management, Paris, France.

Swamy, P. A. V. B., \& Mehta, J. S. (1977). Estimation of linear models with time and cross sectionally varying coefficients. Journal of The American Statistical Association, 72(360), 890-898. http://dx.doi.org/10.1080/01621459.1977.10479978

Wooldridge, J. M. (2003). Introductory econometrics-A modern approach. U.S.A.: South-Western College Publishing.

Yamak, R., Dursun, S., \& Topbaş, F. (2007). Türkiye'de sendikalaşma ve ücretler: 1991-2005 panel nedensellik analizi, 8. Türkiye Ekonometri ve Ístatistik Kongresi, 24-25 Mayıs 2007. 